Prof. Baker's observations leave no doubt that the species of Liomyrmex are true termitophiles and suggest that their relations to the termites are more intimate than those of the species of Carebara, Aëromyrma, Erebomyrma, etc., which seem to be thiefants, living in chambers of their own in the solid masonry of the termitaria and feeding surreptitiously on the termites and their brood.

\title{
THE PHORID GENUS PLATYPHORA IN AMERICA.
}

By Charles T. Brues, Bussey Institution, Harvard University.

In 1877 Verrall described from England a peculiar species of Phoridæ for which he erected the genus Platyphora, calling the insect $P$. lubbocki in honor of its discoverer, Sir John Lubbock, who had found it in an ant nest. Although Verrall's description has often been quoted, no further observations on this genus appeared till 1912, when Becker described as Psalidesma pyrenaicum an European form which he later ascertained was congeneric with Platyphora lubbocki, although specifically distinct. Becker has figured and carefully described this form and by comparison of a drawing of Verrall's type, obtained from Collin, has been able accurately to characterize the genus. Since this, Collin has published a figure of $P$. lubbocki and noted its occurrence in other parts of England.

From Becker's account I have been able to place in Platyphora two American species which have been in my collection for a number of years, that I had considered as probably representing a new genus. The two American forms differ from P. lubbocki only in minor characters, but are distinguished from $P$. pyrenaica by the third vein being bristly and distinctly forked at apex. All are so similar, however, that there can be no question that all should form a single genus.

\section{Platyphora Verrall.}

1877. Journ. Linn. Soc., London, Zoöl., vol. 13, p. 259.

1901. Becker, Abh. zool.-bot. Ges. Wien., vol. 1, p. 88.

1903. Brues, Trans. Amer. Ent. Soc., vol. 29, p. 386.

1906. Brues, Genera Insectorum, fasc. 44, p. 13.

1908. Enderlein. Zoöl. Jahrb. Abth. f. Syst., vol. 27, p. 148.

1910. Malloch, Ann. Scottish Nat. Hist., p, 17. 
1912. Becker, Wiener Ent. Zeit., vol. 31, p. 329 (Psalidesma).

1913. Becker, ibid., vol. 32, p. 19.

1913. Collin, Entom. Monthly Mag., vol. 24, p. 174, fig.

Type: $P$. lubbocki Verrall.

The four species so far recognized may be distinguished as follows:

1. Third vein of wing entirely bare and not forked at apex....P. pyrenaica Becker Third vein bristly to the fork, which is indicated at least weakly $\ldots \ldots \ldots \ldots \ldots 2$

2. Fork of third vein very delicate; segments of abdomen becoming shorter after the second ................................ lubbocki Verrall

3. Fork of third vein well developed; second and sixth segments of abdomen elon-

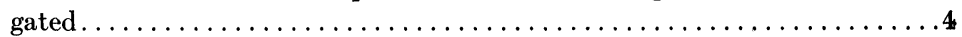

4. Legs and antennæ brownish yellow; scutellum shagreened. P. coloradensis sp. nov. Legs and antennæ black; scutellum polished, shining.....P. eurynota sp. nov.

Platyphora pyrenaica Becker.

Wiener. Ent. Zeit., vol. 31, p. 330, figs. (1912) (Psalidesma).

Becker, ibid., vol. 32, p. 19 (1913).

\section{Platyphora lubbocki Verrall.}

Journ. Linn. Soc., vol. 13, p. 259 (1877).

Lubbock, Ants, Bees and Wasps, p. 371 (1883).

Bezzi. Rendic. Istit. Lom. Sc. Lett., vol. 33, p. 11 (1900).

Becker, Abh. zoöl.-bot. Ges. Wien, vol. 1, p. 88 (1901).

Brues, Trans. Amer. Ent. Soc., vol. 29, p. 316 (1903).

Shelford, Journ. Linn. Soc., London, Zoöl., vol. 30, p. 152 (1908).

Enderlein, Zoöl. Jahrb, Abth. f. Syst., vol. 27, p. 148 (1908).

Becker, Wien. Ent. Zeitg., vol. 32, p. 19 (1913).

Collin, Entom. Monthly, Mag., vol. 24, p. 174, fig. (1913).

\section{Platyphora eurynota sp. nov.}

$0^{7}$. Length, $2.8 \mathrm{~mm}$. Entirely black, except the trochanters which are brownish yellow, and the hypopygium which is piceous, with the lower projection fuscoferruginous; wings hyaline. Head from above slightly more than twice as broad as thick, the hind margin straight and finely margined; anteriorly receding on each side to the margin of the large eye which occupies the entire side of the head when viewed in this position. Laterally the head is very much narrowed below, and not quite so high as the height of the nearly horizontal front. Antennal cavities shallow, each with four small reclinate macrochætæ along its lower margin and a group of three reclinate ones just to the side of the insertion of the palpus. Antennæ with the third joint rounded, rather small, bearing a long, bare arista, fully as long as the width of the front. Cheeks each with a series of minute bristles below the eye, extending upwards to join with the postocular cilia which are very weakly developed. Palpi extremely small, with a tuft of four or five small bristles at the extreme tip. Front highly polished, with scattered hairs, but no macrochætæ although there are a few stouter, bristly hairs along the posterior margin of the vertex. Ocelli large; no frontal groove. Mesonotum large and broad, shining and clothed like the 
front; no dorsocentral macrochætæ, although there is a pair of larger bristly hairs on the posterior margin at this place. Scutellum large, truncate at the sides; shining, without bristles, but with a series of short bristle-like appressed hairs in a close series along the hind margin; twice as broad as long. Mesopleura smooth, bare below, above polished and hairy like the mesonotum, with a large macrochæta at its upper hind angle. Abdomen broad and flat, the second and sixth segments lengthened as in $P$. pyrenaica; basal segments pruinose, but the sixth shining; no hairs or bristles, except at the sides of the fifth and sixth segments which bear hairs, and the posterior margin of the sixth which bears a series of short bristles. Hypopygium small, with a rounded upper surface, two finger-like processes from the left lobe; and several shorter processes from the right lobe. Legs rather slender, without bristles; tibial spurs represented by several minute bristles on the fore leg; those of the middle and hind tibiæ small, but quite distinct; fore and middle coxae below with a few bristles and hairs. Fore tibia much shortened and its tarsus flattened; the metatarsus nearly as long as the tibia. Wings large, with the costa reaching the middle, its bristles very short; third vein bristly as far as the fork, its

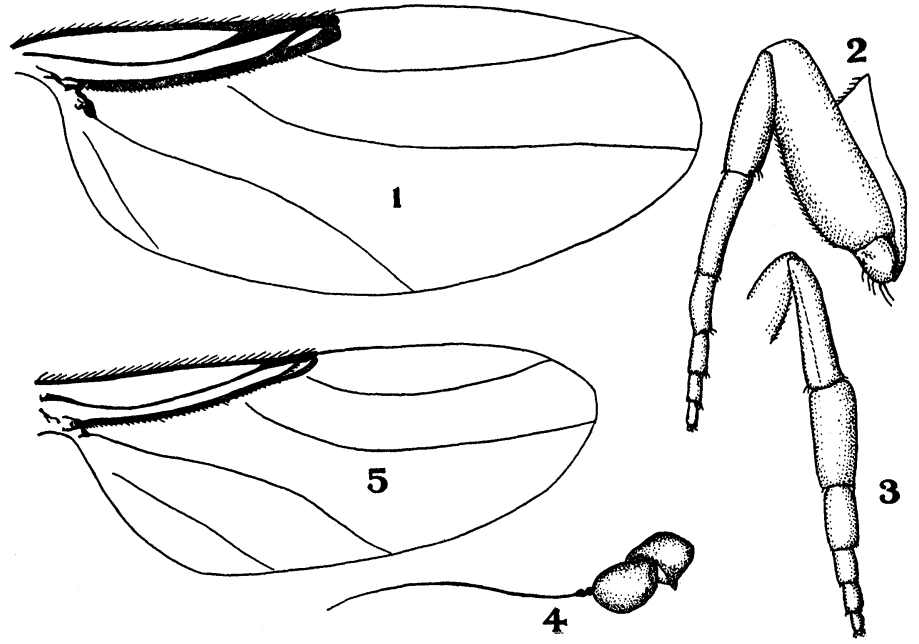

Fig. 1. Platyphora eurynota sp. nov., wing.

2. Front leg of same side view.

3. Front tibia and tarsus of same, external view.

4. Antenna of same.

5. Platyphora coloradensis sp. nov., wing.

bristles almost as long as those on the costa. Third vein distinctly forked; thick ened for its entire length; costa thickened beyond the first vein which is very thin except on the extreme apical portion; heavy veins black; light veins fuscous. Fourth vein slightly curved and faintly recurved at apex; fifth running nearly parallel to the fourth and entering the wing margin just beyond the wing-tip; sixth much bent down on its apical half; seventh distinct. Halteres black, with the extreme base pale. 
Described from a single male collected at Forest Hills, Mass., May 30, 1910, by Mrs. C. T. Brues. The insect was moving about among fallen leaves in an open wooded area. Ants of various kinds are abundant in the vicinity and it is possible that the species may be myrmecophilous like its European congener, $P$. lubbocki.

\section{Platyphora coloradensis sp. nov.}

$\sigma^{7}$. Length $1.8 \mathrm{~mm}$. Black; antennæ dark fulvous, darkened on the tip of the third joint; palpi pale yellow; legs testaceous, tinged with fuscous on the tibiæ and fuscous on the tarsi. Pleuræ pale fuscous, piceous on the posterior half of the mesopleura. Hypopygium retracted, but apparently brownish as in P. eurynota. Head structurally as in P. eurynota, and also the mesonotum, except that the dorsocentral bristles are larger. Scutellum dull, not at all shining, with shagreened surface; the series of bristles along its margin larger than in $P$. eurynota. Abdomen with the second and sixth segments lengthened, slightly pruinose and nearly bare on the first to fifth segments; sixth shining and clothed with sparse hairs. Pleuræ and legs as in $P$. eurynota. Wings hyaline; heavy veins pale brown, except the apex of the costal vein which is fuscous; light veins very pale; costal bristles larger than in $P$. eurynota; third vein bristly to the fork and second vein bristly; third vein thickened, but not much stouter than the costa, light veins much as in P. eurynota, but the fourth and fifth are less divergent at tip and the seventh apparently farther from the margin. Halteres black, except at extreme base.

Described from a single specimen collected on a window at Boulder, Col., by Mrs. T. D. A. Cockerell, July 17, 1908, and sent to me by Prof. Cockerell.

This species is very similar to $P$. eurynota in structure, although entirely different in color and much smaller. It might perhaps be considered as a mere color variety, but the scutellum is dull and the wing venation is not identical, so it appears to be a perfectly distinct, but allied species.

\section{DESCRIPTIONS OF TWO NEW GENERA OF PARASITIC HYMENOPTERA.*}

\section{By S. A. RoHwer.}

The following new genera and species are parasites of two insects which have been proven to be of economic importance in relation to the chestnut. The descriptions are offered at the present time

\footnotetext{
* A contribution from Branch of Forest Insects, Bureau of Entomology, Washington, D. C.
} 

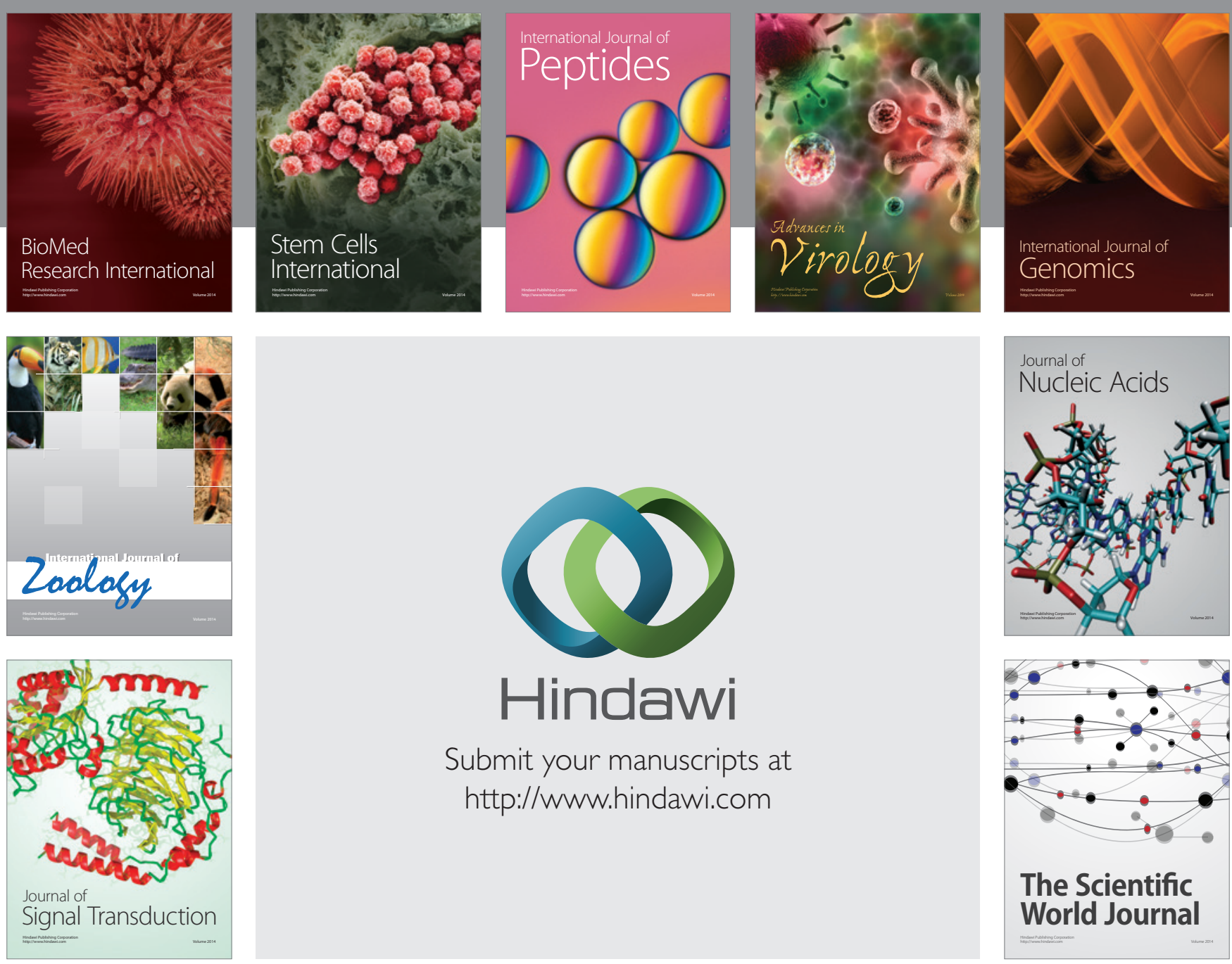

Submit your manuscripts at

http://www.hindawi.com
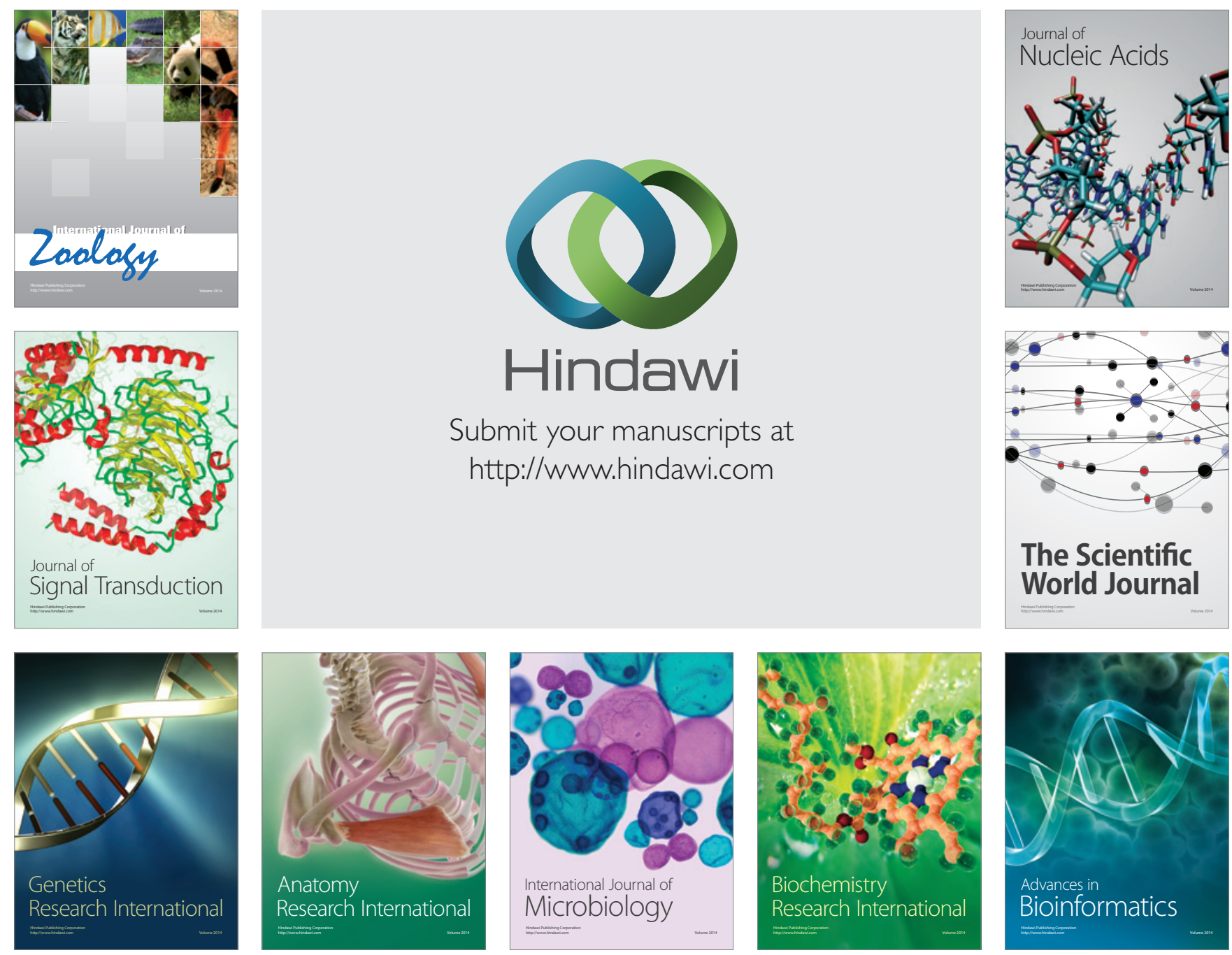

The Scientific World Journal
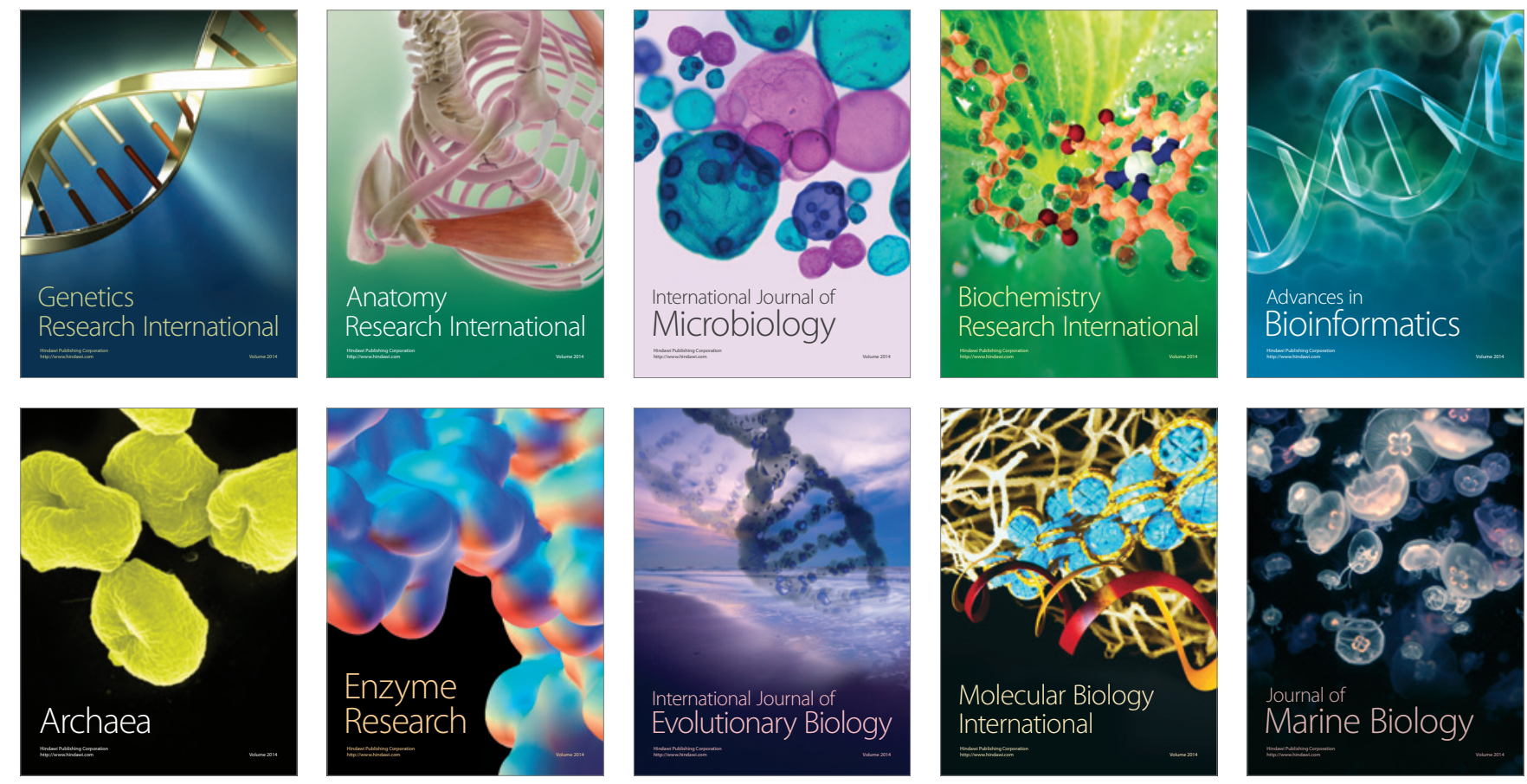